Article

\title{
Effect of Warm Rolling Temperature on the Microstructure and Texture of Microcarbon Dual-Phase (DP) Steel
}

\author{
Qiangqiang Yuan, Zhigang Wang *, Yinghui Zhang *, Jieyun Ye, Yao Huang and Ankang Huang \\ School of Material Science and Engineering, Jiangxi University of Science and Technology, Ganzhou 341000, \\ China; 13576897221@163.com (Q.Y.); yejieyun2008@163.com (J.Y.); taohua-daozhu@163.com (Y.H.); \\ hak1365947268@163.com (A.H.) \\ * Correspondence: wzgang2008cn@163.com (Z.W.); jxustzyh@163.com (Y.Z.); Tel.: +86-0791-8314-422 (Z.W.); \\ +86-0791-8314-421 (Y.Z.)
}

Received: 29 February 2020; Accepted: 23 April 2020; Published: 27 April 2020

\begin{abstract}
The effect of warm rolling temperature on microstructure and texture of microcarbon dual-phase (DP) steel was investigated through scanning electron microscopy (SEM), electron backscatter diffraction (EBSD), and transmission electron microscopy (TEM). The results showed that with the increase of rolling temperature, the density and thickness of the deformation band first increased and then decreased. Ferrite and fine martensite were observed in the annealed sheet, and the ferrite had a much more homogeneous distribution in the sample rolled at $450{ }^{\circ} \mathrm{C}$. During warm rolling, the ferrite developed a dominant $\gamma$-fiber and a weak $\alpha$-texture. During the annealing of the rolled sheet, the intensity of the $\gamma$-fiber was increased and a weak $\{001\}<100>$ texture developed in the sample rolled at room temperature. An increase in the rolling temperature generated an initial decrease and subsequent increase in the strength of the unfavorable $\{001\}<110>$ texture in the annealed sheet. In addition, the strength reached a maximum at $550{ }^{\circ} \mathrm{C}$ due to an increase in the dissolved carbon in the matrix, which was result of carbide dissolution. By contrast, the intensity of the $\gamma$-fiber remained relatively higher and was deemed the weaker $\{001\}<110>$ component in the annealed sheet rolled at $450{ }^{\circ} \mathrm{C}$. Therefore, a larger texture factor $\left(f_{\gamma-\text { fiber }} / f_{(\alpha-\text {-fiber }+\lambda \text {-fiber })}\right)$ can be produced under this process.
\end{abstract}

Keywords: $\mathrm{Nb}-\mathrm{Cr}$ micro-alloying steel; warm rolling; texture; microstructures; deformation band

\section{Introduction}

Warm rolling technology is an effective method is used to improve the strength and deep-drawing properties of advanced high-strength steel (AHSS). In general, the tensile strength of interstitial free (IF) and bake-hardenable (BH) steel hardly exceeds $500 \mathrm{MPa}$ because of the single ferrite matrix $[1,2]$. Ordinary high-strength or ultra-high-strength steels, such as dual-phase (DP) and transformation-induced plasticity (TRIP) steel, generate poor deep drawing properties and R-values that generally do not exceed 1.2 due to the abundance of $C$ in solid solution in the matrix [3]. Due to the influence of the $\mathrm{C}$ atoms in the solid solution, development of the deep drawing texture (mainly consisting of $\gamma$-fiber) in microcarbon steel is not as complete as that in ultra-low carbon steel. Han et al. [4] presented a method to control the amount of $C$ in the solid matrix solution via the low-temperature precipitation and high-temperature dissolution of the precipitates with chrome $(\mathrm{Cr})$ and molybdenum (Mo). Wang et al. [5] found that the intensity of $\{001\}<110>$ was significantly reduced by fixing the amount of $C$ in the solid solution of Cr-Mo DP steel. Barnett [6] and Jonas [7] observed a very favorable in-grain shear band for the formation of $\gamma$-fiber in IF steels or low carbon (LC) steels, which is conducive for the development of the deep drawing texture. However, the low-temperature 
deformation test results indicated the presence of very few shear bands and negative strain rate sensitivity ( $\mathrm{m}$ ) in the LC steel [8], resulting in the generation of dynamic strain aging (DSA) behavior. Many reports indicated the abundance of DSA behavior in LC steel at lower rolling temperatures, which inhibits the formation of shear bands and worsens the deep drawing texture $[9,10]$. Therefore, it is necessary to avoid or delay the DSA temperature region during the warm rolling of LC steel. Mohammad et al. [11] found that the addition of microalloying elements, such as $\mathrm{Cr}$, can delay the DSA behavior. In addition, the in-grain shear band can also be generated during warm rolling at low temperatures. Cuddy and Leslie [12] reported similar conclusions, wherein the DSA behavior can be inhibited the C-Cr atom pair as well as the successful generation of shear bands after warm rolling.

$\mathrm{Cr}$ can increase the shear band contents, inhibit DSA behavior by forming large-sized precipitates, and improve tensile properties [13]. In addition, the present work also added $\mathrm{Nb}$ in the tested steel with the aim of fixing the $\mathrm{C}$ component in the solid solution. $\mathrm{Nb}$ has a strong affinity to $\mathrm{C}$, allowing $\mathrm{C}$ atom pinning in the solid solution by forming precipitates and promoting favorable texture formation, including $<111>/ / \mathrm{ND}(\{111\} / /$ normal direction) fiber and $\{554\}<225>$ component [14]. Hoseini and Anijdan [15] reported that $\mathrm{Nb}$ can intensify the $\{111\}$ texture, particularly the $\{111\}<112>$ component following $400{ }^{\circ} \mathrm{C}$ rolling. In addition, the $\mathrm{NbC}$ precipitates were reportedly able to strengthen the matrix [16].

The present study reported the effect of the warm rolling temperature on the microstructure and texture of the $\mathrm{C}-\mathrm{Cr}-\mathrm{Nb}$ DP steel during warm rolling and annealing. The main focus was the influence of the rolling temperature on the $\gamma$-fiber texture and $\alpha$-fiber texture given that the former is favorable to deep drawabilities. Meanwhile, the evolution of the microstructure and texture was investigated and the causes of the texture formation and disappearance were further analyzed by scanning electron microscopy (SEM), electron backscatter diffraction (EBSD), and transmission electron microscopy (TEM). The results of this study provide the theoretical and parametric support for the warm rolling design process of microcarbon DP steel.

\section{Experimental Methods}

Table 1 presents the chemical compositions of the experimental steel, in which rare earth (RE) elements were employed to purify the molten steel [17]. The tested steel was smelted in a $25 \mathrm{~kg}$ vacuum induction melting furnace and forged into a stock with dimensions of $90 \mathrm{~mm} \times 60 \mathrm{~mm} \times 30 \mathrm{~mm}$.

Table 1. Chemical composition of investigated alloys in mass fraction (\%).

\begin{tabular}{cccccccccc}
\hline $\mathbf{C}$ & $\mathbf{S i}$ & $\mathbf{M n}$ & $\mathbf{P}$ & $\mathbf{S}$ & $\mathbf{N b}$ & $\mathbf{C r}$ & $\mathbf{A l}$ & $\mathbf{N}$ & $\mathbf{R E}$ \\
\hline 0.034 & 0.39 & 1.3 & 0.044 & 0.007 & 0.052 & 0.044 & $<0.01$ & 0.003 & 0.014 \\
\hline
\end{tabular}

Figure 1 presents a schematic illustration of the manufacture process. The forged billet was heated and soaked at $1200^{\circ} \mathrm{C}$ for $2 \mathrm{~h}$. The specimens were then hot-rolled to $5 \mathrm{~mm}$ at a finishing temperature of $870{ }^{\circ} \mathrm{C}$ and cooled at $700{ }^{\circ} \mathrm{C}$ held for $1.5 \mathrm{~h}$ to simulate the coiling process. The hot-rolled specimens were heated to a rolling temperature $\left(250^{\circ} \mathrm{C}\right.$ to $550^{\circ} \mathrm{C}$, interval: $\left.100^{\circ} \mathrm{C}\right)$ that was maintained for $30 \mathrm{~min}$, fed into the roll mill to generate 2-mm-thick specimen under a single pass, and finally quenched in water. Subsequently, the annealing process was performed on the bright annealing furnace (Type: SK-10-13H, Beijing Yanbei Jianxing Boiler Industry Co.,Ltd., Beijing, China), to which the specimens were heated to $830^{\circ} \mathrm{C}$ (heating rate: $8{ }^{\circ} \mathrm{C} \mathrm{S}^{-1}$; $\mathrm{AC} 1: 780^{\circ} \mathrm{C}$; and AC3: $900{ }^{\circ} \mathrm{C}$, which was calculated using JMatPro 9.0 software, England) and held for $120 \mathrm{~s}$ under nitrogen gas and then rapidly cooled to room temperature using cool water.

The microstructure and texture observed in RD-ND (rolling direction and normal direction) plane using scanning electron microscopy (SEM, Carl Zeiss AG, Jena, Germany) coupled with electron backscattered diffraction (EBSD; OXFORD Corporation, Oxford Instrument Technology Co., Ltd., Shanghai, China) with Channel 5.0 HKL software (Tango, Mambo and Salsa model, 
$\varphi 2=45^{\circ}$ cross-section, OXFORD). The EBSD-related experimental parameters are detailed as follows: a working voltage of $20 \mathrm{kV}$, a working distance of $15 \mathrm{~mm}$, and a step size between $0.28 \mu \mathrm{m}$ and $0.36 \mu \mathrm{m}$. In all of the descriptions, the $\alpha-, \gamma-$, and $\lambda$-fibers were equivalent to $<110>/ / \mathrm{RD},<111>/ / \mathrm{ND}$, and $<100>/ /$ RD. TEM specimen preparation was applied as follows: thin slices were cut from a 2-mm thick sheet with wire cutter and ground to $50 \mu \mathrm{m}$ and then punched into a circle with a diameter of $3 \mathrm{~mm}$; the $5 \%$ perchlorate alcohol solution was used for electropolishing; and the voltage was set between $30 \mathrm{~V}$ and $40 \mathrm{~V}$. The SEM and EBSD specimens were applied by mechanical polishing and electropolishing.

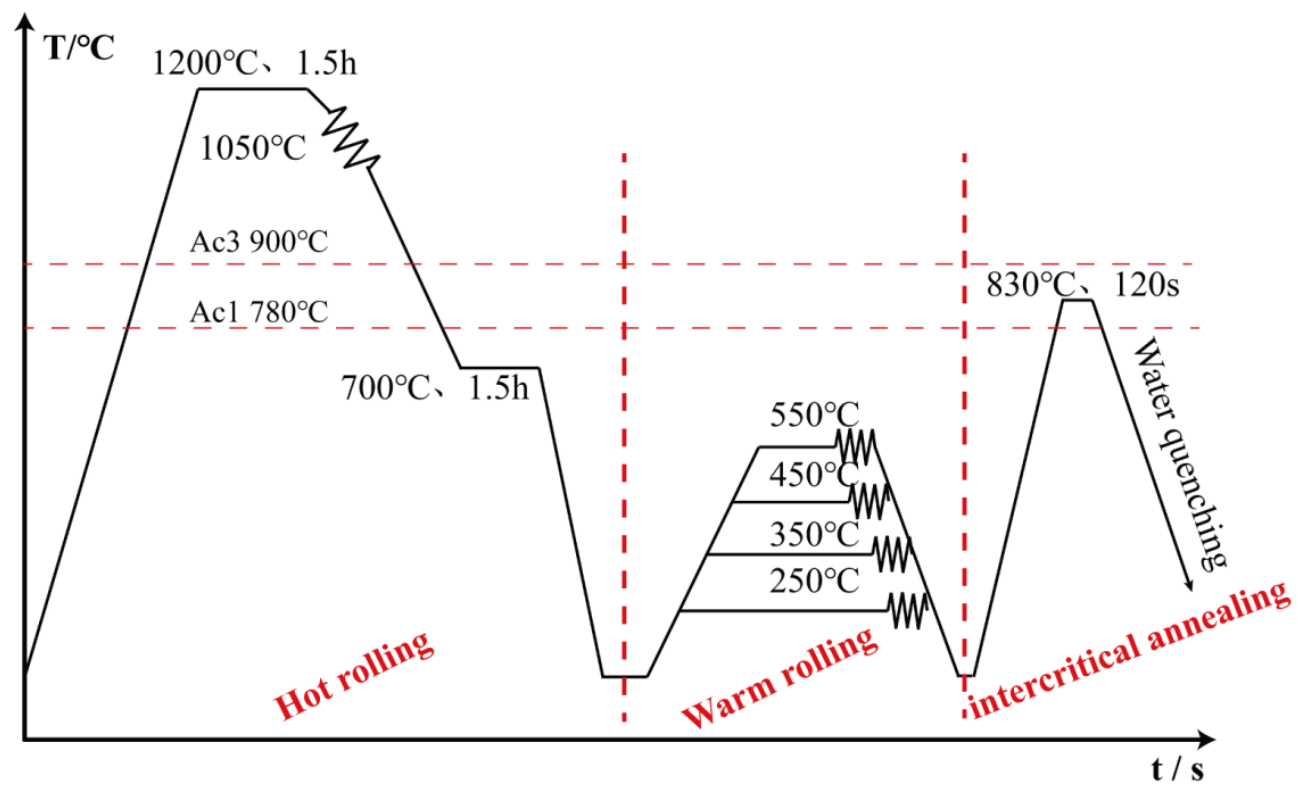

Figure 1. Schematic illustration of the manufacturing process.

\section{Results}

\subsection{Microstructure Feature}

The warm rolling temperature significantly influences the thickness and distribution of the deformation band [18]. Figure 2a presents the warm-rolled microstructure composed of a small pearlite block (red dotted line frame) in the matrix. Figure $2 b, c$ present the grain boundary carbides and pearlite fiber band, respectively, that may have been caused by the fragmentation of pearlite in the hot-rolling sheet after room temperature rolling. The ferrite elongated along the RD-direction (Figure 2c-f). The elongated pearlite bands and a wide ferrite deformation band thickness were observed at $250{ }^{\circ} \mathrm{C}$ (Figure 2c). At $350{ }^{\circ} \mathrm{C}$, the deformation band thickness was similar to that at $250{ }^{\circ} \mathrm{C}$, though a significantly reduced deformation pearlite band was observed. A more refined deformation band was detected at a temperature of $450^{\circ} \mathrm{C}$ and at the highest density (proportion of the deformation bands area in the total field), during which the large size carbides disappeared to present a more uniform deformation. The deformation degree dramatically decreased and the band thickness significantly widened at $550{ }^{\circ} \mathrm{C}$ possibly due to the dynamic recovery at this temperature. 

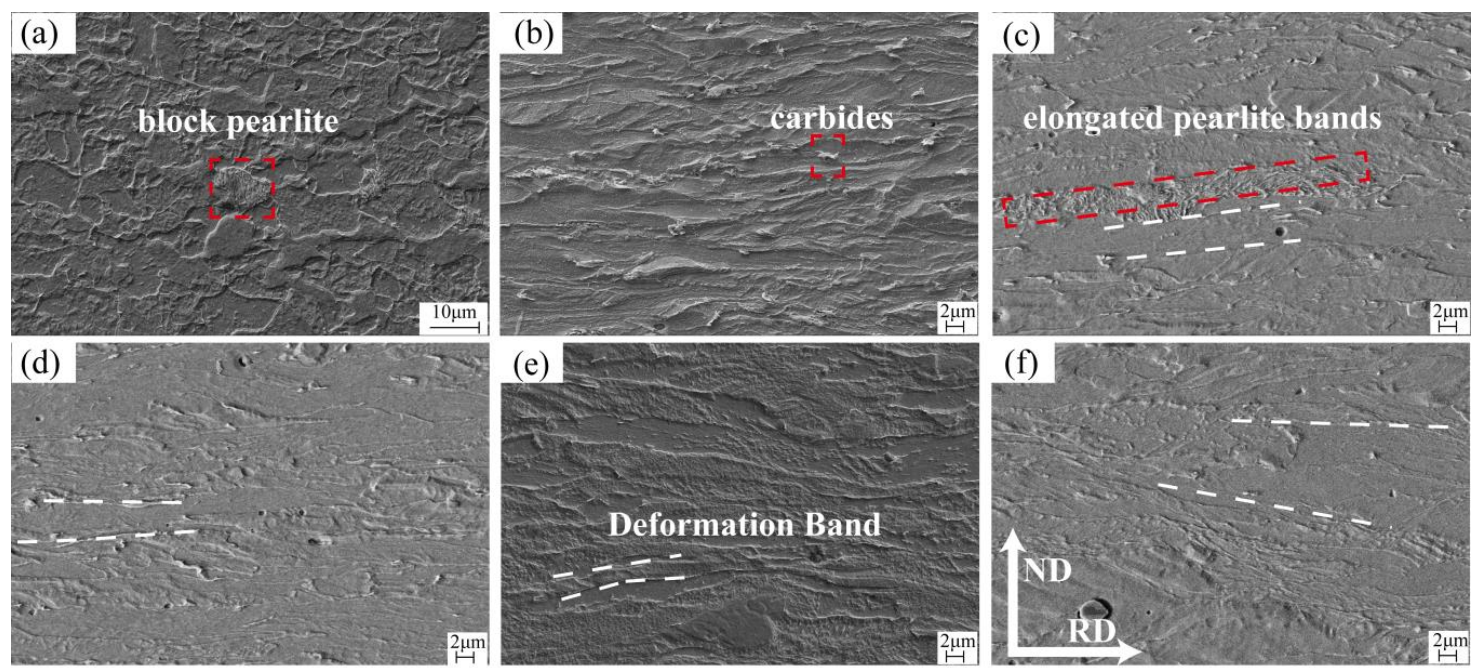

Figure 2. The hot rolling, room temperature, and warm rolling specimen microstructures. (a) Hot rolling: block pearlite; (b) room temperature rolling: carbides; (c) $250{ }^{\circ} \mathrm{C}$ : elongated pearlite bands; (d) $350{ }^{\circ} \mathrm{C}$ : widened band; (e) $450{ }^{\circ} \mathrm{C}$ : refined deformation band; and (f) $550{ }^{\circ} \mathrm{C}$ : widened band again.

Figure 3 presents the annealing microstructure, which is composed of ferrite and martensite. The deformed ferrite grain has a finishing recrystallization that tended to be equiaxed. The martensite grain size was larger and the distribution was uneven compared to the specimen that was rolled at room temperature. However, the specimen below $350{ }^{\circ} \mathrm{C}$ was not completely recrystallized given the presence of some thin deformed bands after annealing (red dotted line in Figure 3b,c), which may be a result of the stored energy, wherein obvious martensite aggregation was observed at room temperature and at $350^{\circ} \mathrm{C}$ (red dotted box in Figure 3a,c). The deformed band disappeared, a relatively clear grain boundary was observed when the rolling temperature was increased to $450{ }^{\circ} \mathrm{C}$ (Figure 3e). In addition, Figure $3 \mathrm{f}$ indicates the presence of a martensite island in the ferrite grain boundary. The ferrite grain size and martensite distribution at $550{ }^{\circ} \mathrm{C}$ were less uniform than at $450{ }^{\circ} \mathrm{C}$.
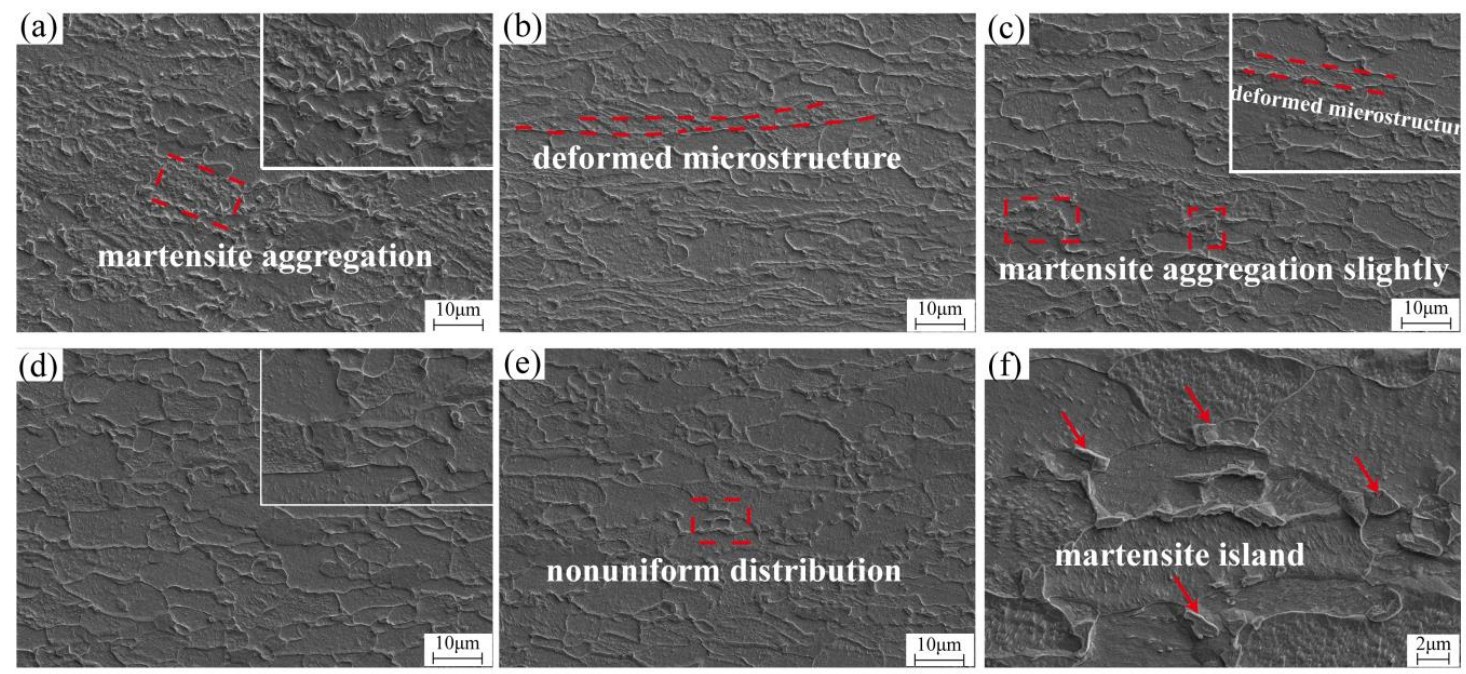

Figure 3. SEM microstructure after annealing. (a) Room Temperature: martensite aggregation; (b) $250{ }^{\circ} \mathrm{C}$ : vestigial bands; (c) $350{ }^{\circ} \mathrm{C}$ : slight martensite aggregation; (d) $450{ }^{\circ} \mathrm{C}$ : uniform distribution; and $(\mathbf{e}, \mathbf{f}) 550^{\circ} \mathrm{C}$.

\subsection{Texture Feature}

Figure 4 presents the orientation distribution function (ODF) diagram of the $\varphi 2=45^{\circ}$ section of the warm-rolled sheet and the frequency of the warm-rolled texture. Slightly different grain 
orientation distributions as well as significant differences in intensity were observed at different rolling temperatures. The rise in the rolling temperature generated an initial increase and subsequent decrease in the intensity of $\{001\}<110>$, reaching a maximum at $450{ }^{\circ} \mathrm{C}$ (Figure $4 \mathrm{~d}$ ). The $\{001\}<100>$ and $\{001\}<100>$ components were observed at room temperature (Figure $4 \mathrm{a}$ ) and $250{ }^{\circ} \mathrm{C}$ (Figure $4 \mathrm{~b}$ ). The intensity of the $\gamma$-fiber after warm rolling was stronger than when rolled at room temperature except at $550{ }^{\circ} \mathrm{C}$ (Figure $4 \mathrm{e}$ ). A strong $\{001\}<110>$ component was observed at both $350{ }^{\circ} \mathrm{C}$ (Figure $4 \mathrm{c}$ ) and $450{ }^{\circ} \mathrm{C}$ (Figure $4 \mathrm{~d}$ ). Figure $4 \mathrm{f}$ presents the volume fraction of several typical texture orientations and texture factors $\left(f_{\gamma \text {-fiber }} / f_{(\alpha \text {-fiber }+\lambda \text {-fiber })}\right)$ [19], wherein the volume fraction of the $\{111\} / / \mathrm{ND}$ texture reached a peak at $450^{\circ} \mathrm{C}$, which was conducive to the formation of the $\gamma$-fiber. In comparison, a mere $22 \%$ of the $\gamma$-fiber was observed at $550{ }^{\circ} \mathrm{C}$ (Figure $4 \mathrm{f}$ ). The content of the $<100>/ / \mathrm{ND}$ texture was less than that of the $\{111\} / / \mathrm{ND}$ texture, which was mainly concentrated on the $\{001\}<110>$ texture at both $350{ }^{\circ} \mathrm{C}$ and $450{ }^{\circ} \mathrm{C}$. The $450^{\circ} \mathrm{C}$ and $550^{\circ} \mathrm{C}$ specimens presented the lowest and highest $\alpha$-fiber contents, respectively. In addition, the $450^{\circ} \mathrm{C}$ specimen exhibited the largest texture factor, as shown in Figure $4 \mathrm{f}$ for $\{111\} /\{110\}+\{100\}$. The rolling temperature greatly affected the $\gamma$-fiber and $\{001\}<110>$ content. Warm rolling was highly unlikely to produce $\{001\}<100>$ as compared to rolling at room temperature. $\{001\}<110>$ was more easily produced between $250{ }^{\circ} \mathrm{C}$ and $450{ }^{\circ} \mathrm{C}$. In addition, warm rolling at $550{ }^{\circ} \mathrm{C}$ was more prone to generating $\alpha$-fiber.
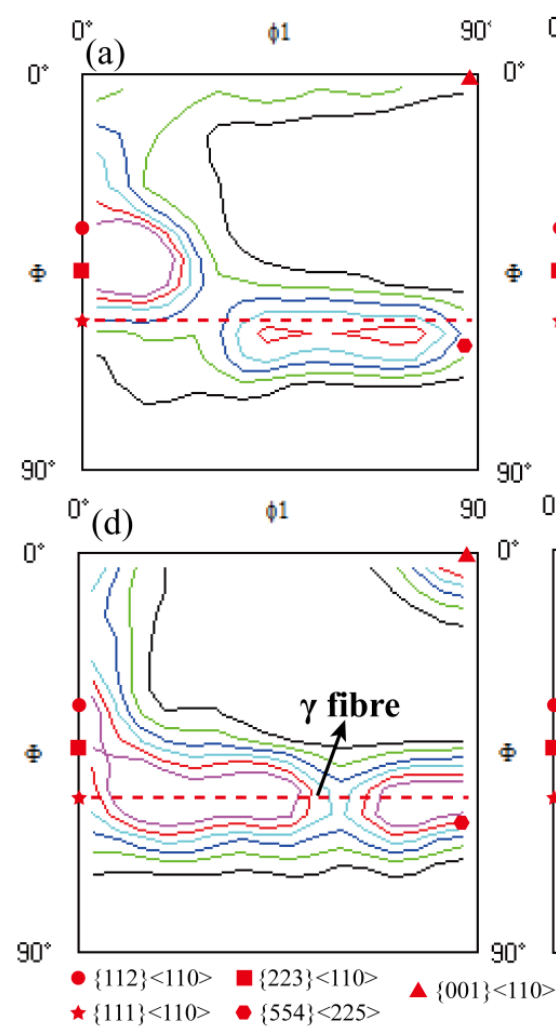
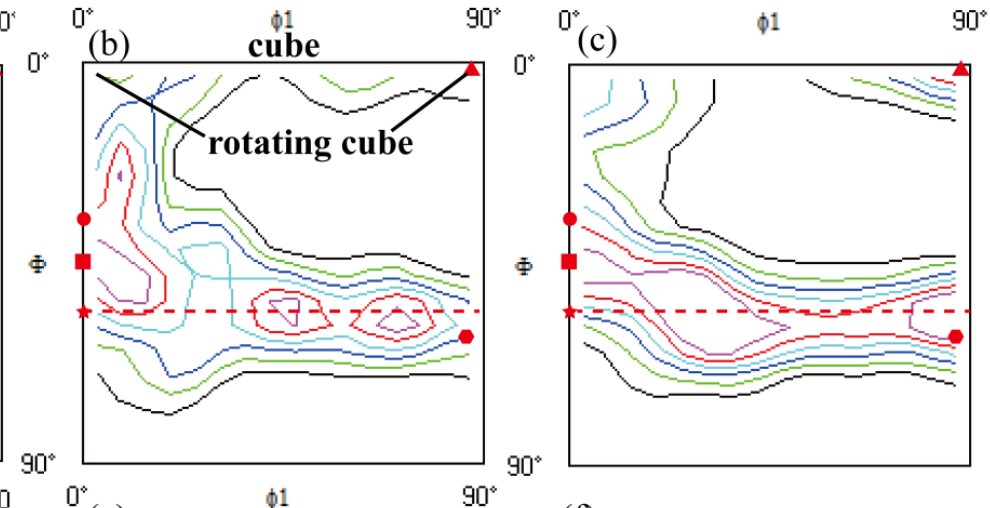

(f)

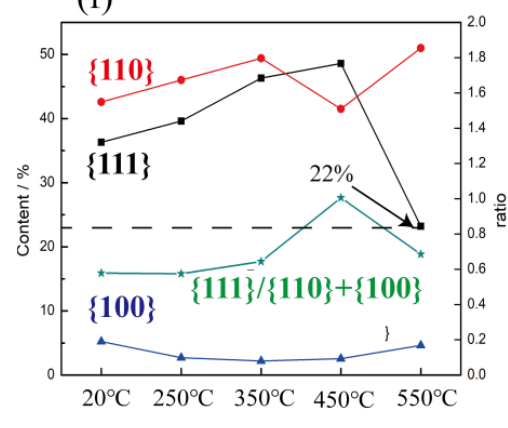

Warm Rolling temperature

Figure 4. ODF (Orientation distribution function) diagram of the $\varphi 2=45^{\circ}$ section of the warm-rolled sheet. (a) RT; (b) $250^{\circ} \mathrm{C}$; (c) $350{ }^{\circ} \mathrm{C}$; (d) $450{ }^{\circ} \mathrm{C}$; (e) $550{ }^{\circ} \mathrm{C}$; and (f) warm-rolled texture volume fraction.

Figure 5 presents the orientation density line of the warm-rolled sheet. The main texture of the $\alpha$-fiber shifted from $\{223\}<110>$ to $\{112\}<110>$ with the increase in temperature, wherein the weakest $\{001\}<110>$ content was observed at lower temperatures (room temperature and $250{ }^{\circ} \mathrm{C}$ ). The orientation density presented significant increases between $350{ }^{\circ} \mathrm{C}$ and $550{ }^{\circ} \mathrm{C}$. Figure $5 \mathrm{~b}$ shows the $\gamma$-fiber density of the warm-rolled sheet. The total density line showed high intensity at $450{ }^{\circ} \mathrm{C}$, especially the $\{111\}<123>$ component. In addition, other rolling temperatures exhibited relatively weak orientation densities, especially at $550{ }^{\circ} \mathrm{C}$. 

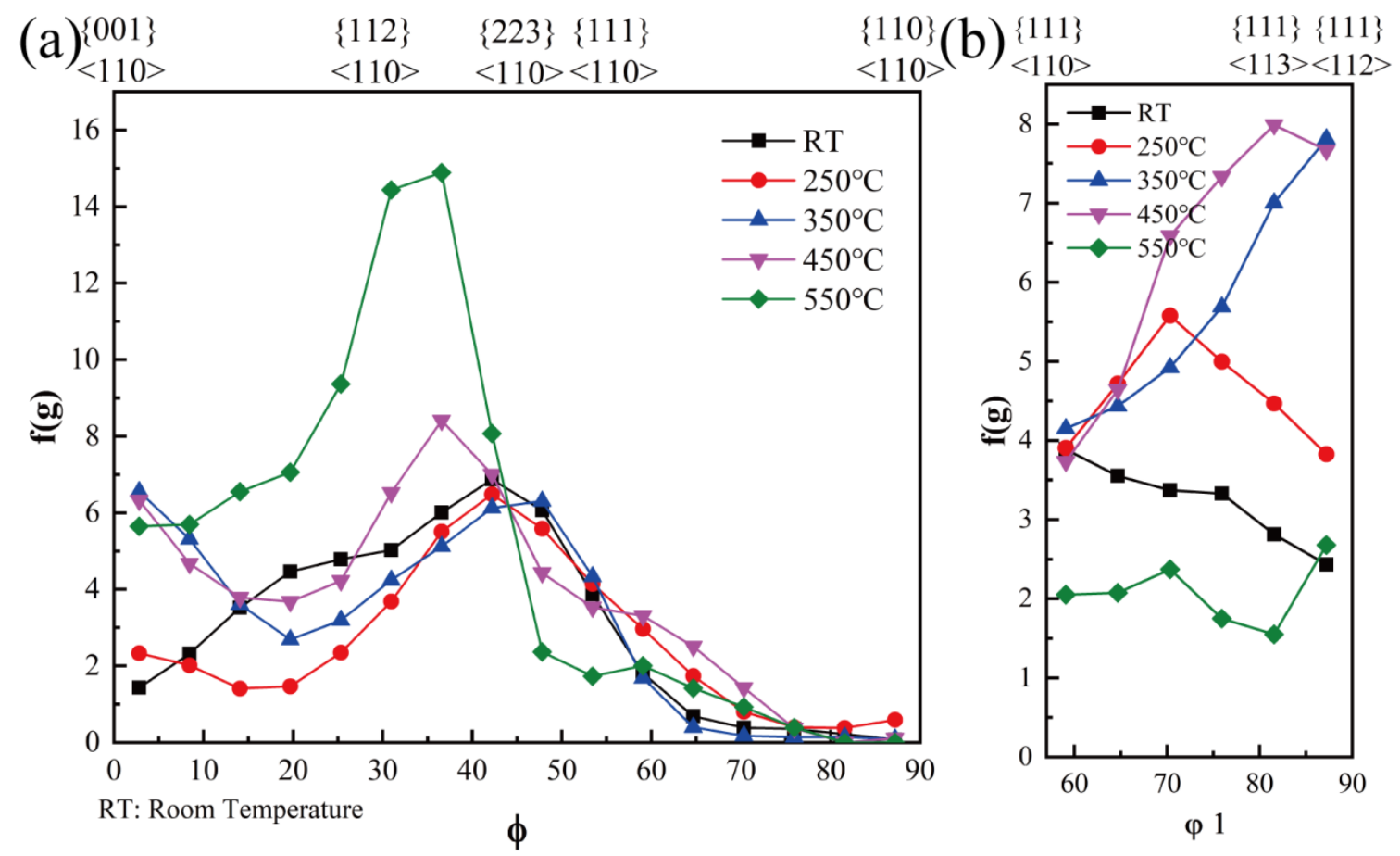

Figure 5. Orientation density at different rolling temperatures. (a) $\alpha$-Orientation: strong intensity between $\{112\}<110>$ and $\{223\}<110>$; and (b) $\gamma$-orientation: high density at $450{ }^{\circ} \mathrm{C}$.

Figure 6 presents texture that was mainly concentrated in the $\alpha$ - and $\gamma$-fiber lines after annealing, wherein different intensities were presented. Although strong $\gamma$-fiber and $\{001\}<110>$ components were observed at room temperature, a weak $\{001\}<001>$ component was still present. An increase in the temperature resulted in the disappearance of $\{001\}<100>$ as well as an obvious decrease in $\{001\}<110>$ intensity. Weak $\gamma$-recrystallization fiber and strong $\alpha$-recrystallization fiber was detected following rolling at $250^{\circ} \mathrm{C}$ and $350^{\circ} \mathrm{C}$, indicating these temperatures were not conducive to the deep drawing properties. However, the $\gamma$-fiber enhanced, a strong $\{554\}<225>$ component, and almost no $\{001\}<100>$ and $\{001\}<110>$ were observed at $450^{\circ} \mathrm{C}$. Better developed $\{111\}<112>$ and $\{554\}<225>$ adjacent components were detected at $550^{\circ} \mathrm{C}$. In addition, $\{001\}<110>$ exhibited enhanced intensity and the $\{110\}<223>$ components was also observed. Figure $6 \mathrm{f}$ presents the volume fraction of several typical orientations of annealed sheet. The $\{110\}$ texture content exhibited an inverse relationship with the temperature. The $\{111\}$ texture content reached a maximum value at $450{ }^{\circ} \mathrm{C}$, which accounted for about $47 \%$ of the total content. 


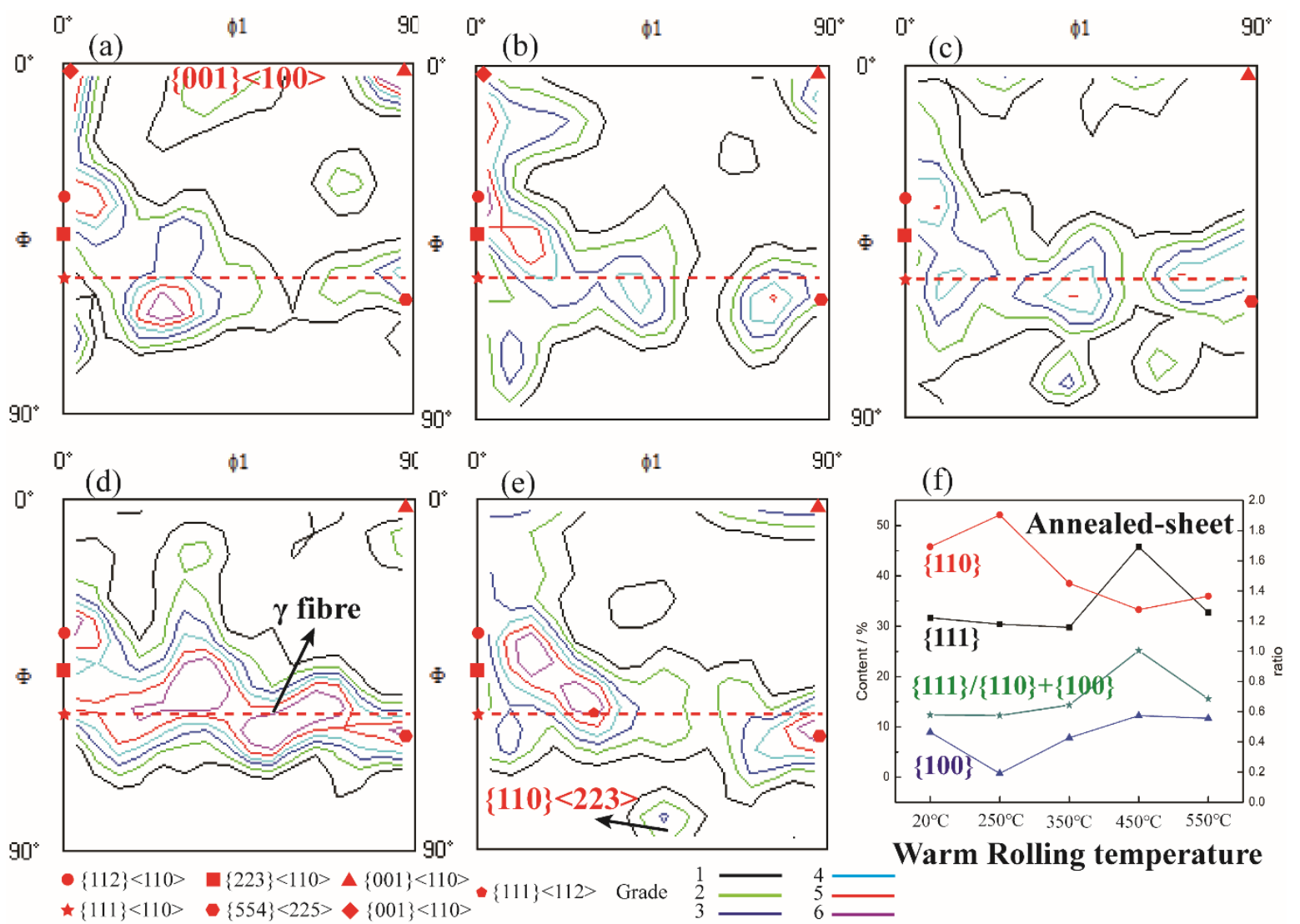

Figure 6. Annealing textures for the specimens. (a) RT: strong cubic component; (b) $250{ }^{\circ} \mathrm{C}$ : weak $\gamma$ and strong $\alpha$; (c) $350{ }^{\circ} \mathrm{C}$ : same conditions as $250{ }^{\circ} \mathrm{C}$; (d) $450{ }^{\circ} \mathrm{C}$ : strong $\gamma$-fiber; (e) $550{ }^{\circ} \mathrm{C}$; and (f) annealing texture volume fraction.

Figure 7 presents the $\alpha$ - and $\gamma$-fiber density calculation results. The density of the unfavorable texture was higher in the adjacent $\{001\}<110>$ and $\{221\}<110>$ components at room temperature. At $250{ }^{\circ} \mathrm{C}$, the $\alpha$-recrystallization texture was concentrated between $\{001\}<110>$ and $\{111\}<110>$. Weak $\alpha$-recrystallization texture was observed at $350{ }^{\circ} \mathrm{C}$, whereas higher density was observed in the adjacent $\{112\}<110>$ content at $550{ }^{\circ} \mathrm{C}$, indicating relatively low $\gamma$-recrystallization texture that was still not conducive to the deep drawing properties (Figure $7 \mathrm{~b}$ ). Nevertheless, at $450{ }^{\circ} \mathrm{C}$, the specimen exhibited strong $\gamma$-recrystallization texture. In addition, density of $\{112\}<110>$ orientation was two-fold higher than that of the $\{111\}<110>$ orientation in Figures $6 \mathrm{~d}$ and $7 \mathrm{~b}$ due to the texture inheritance. 

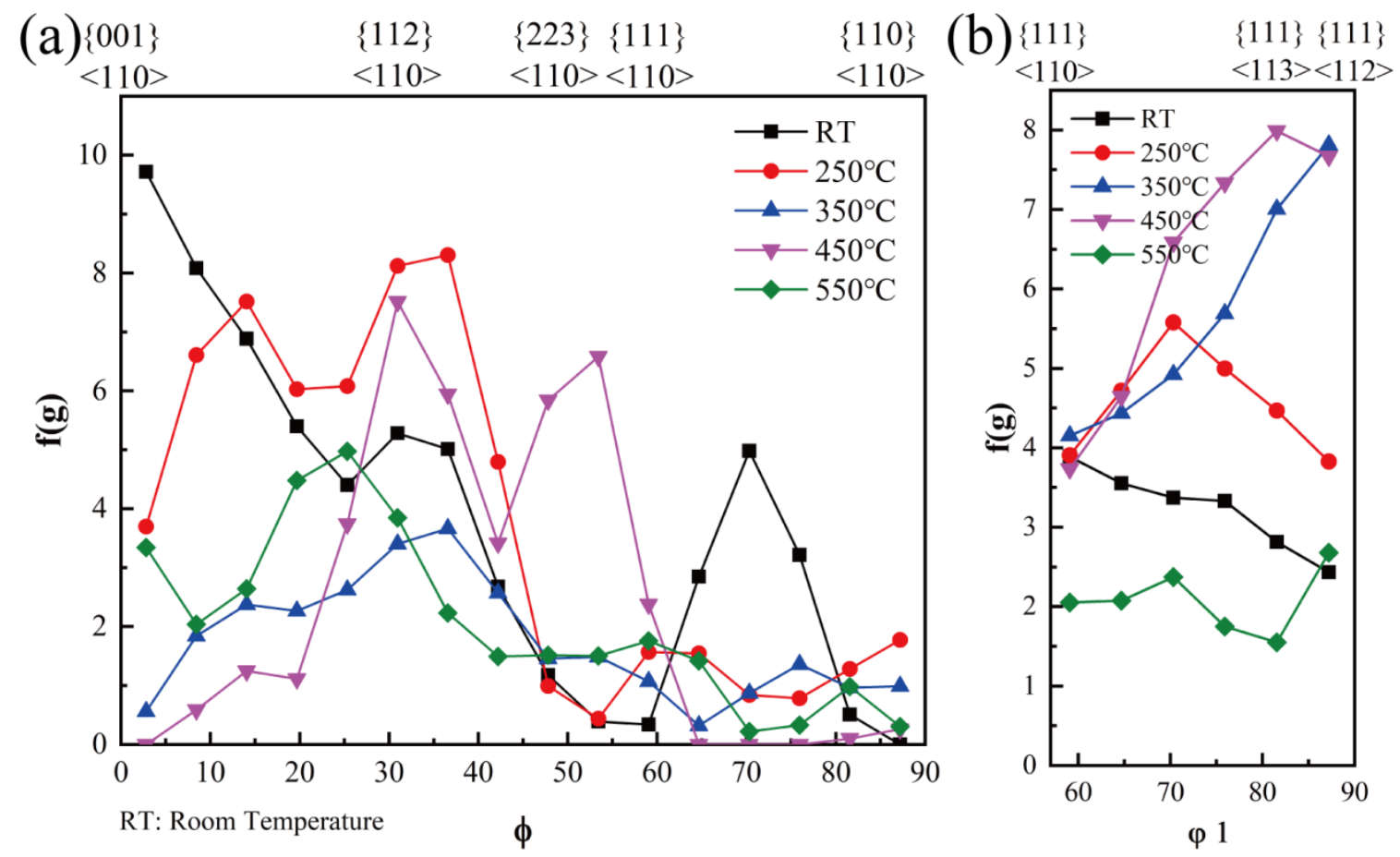

Figure 7. Orientation density after annealing: (a) $\alpha$-orientation; and (b) $\gamma$-orientation.

The texture evolution beginning from the warm rolling to annealing was further analyzed. Figure 8 lists the eight typical textures that were analyzed, wherein the intensity of the $\gamma$-fiber and $\{554\}<225>$ component increased with temperature from $250{ }^{\circ} \mathrm{C}$ to $450{ }^{\circ} \mathrm{C}$. The textures slightly weakened after annealing and reached a relative balance at $450{ }^{\circ} \mathrm{C}$. Although the $\gamma$-fiber content increased after annealing the $550^{\circ} \mathrm{C}$ specimen, it was still weak possibly due to the dynamic recovery. The $\alpha$-deformation texture content first decreased and then increased across the temperature range of room temperature to $550{ }^{\circ} \mathrm{C}$, during which the lowest content was observed at $450{ }^{\circ} \mathrm{C}$, at which time all of the content decreased after annealing. The $\gamma$-fiber only increased or remained stable after annealing when the $\{223\}<110>$ and $\{112\}<110>$ contents exceeded $20 \%$ in the warm-rolled sheet, such that the $\gamma$-fiber increased after annealing. The $\{001\}<110>$ density of the $\lambda$-fiber significantly decreased after annealing at $350^{\circ} \mathrm{C}$ as compared to annealing at room temperature or at $250{ }^{\circ} \mathrm{C}$. Warm rolling was able to greatly reduce the influence of $\{001\}<100>$ and $\{001\}<110>$. In summary, rolling within the temperature range of $250{ }^{\circ} \mathrm{C}$ to $450{ }^{\circ} \mathrm{C}$ exhibited significantly higher texture factors as compared to other temperatures (Table 2). Moreover, maximum texture factor strength was observed at $450{ }^{\circ} \mathrm{C}$ for both the warm-rolled and annealed specimen, indicating optimized deep drawing properties, as indicated by the results presented in Figures $4 \mathrm{f}$ and $6 \mathrm{f}$ (green line). 


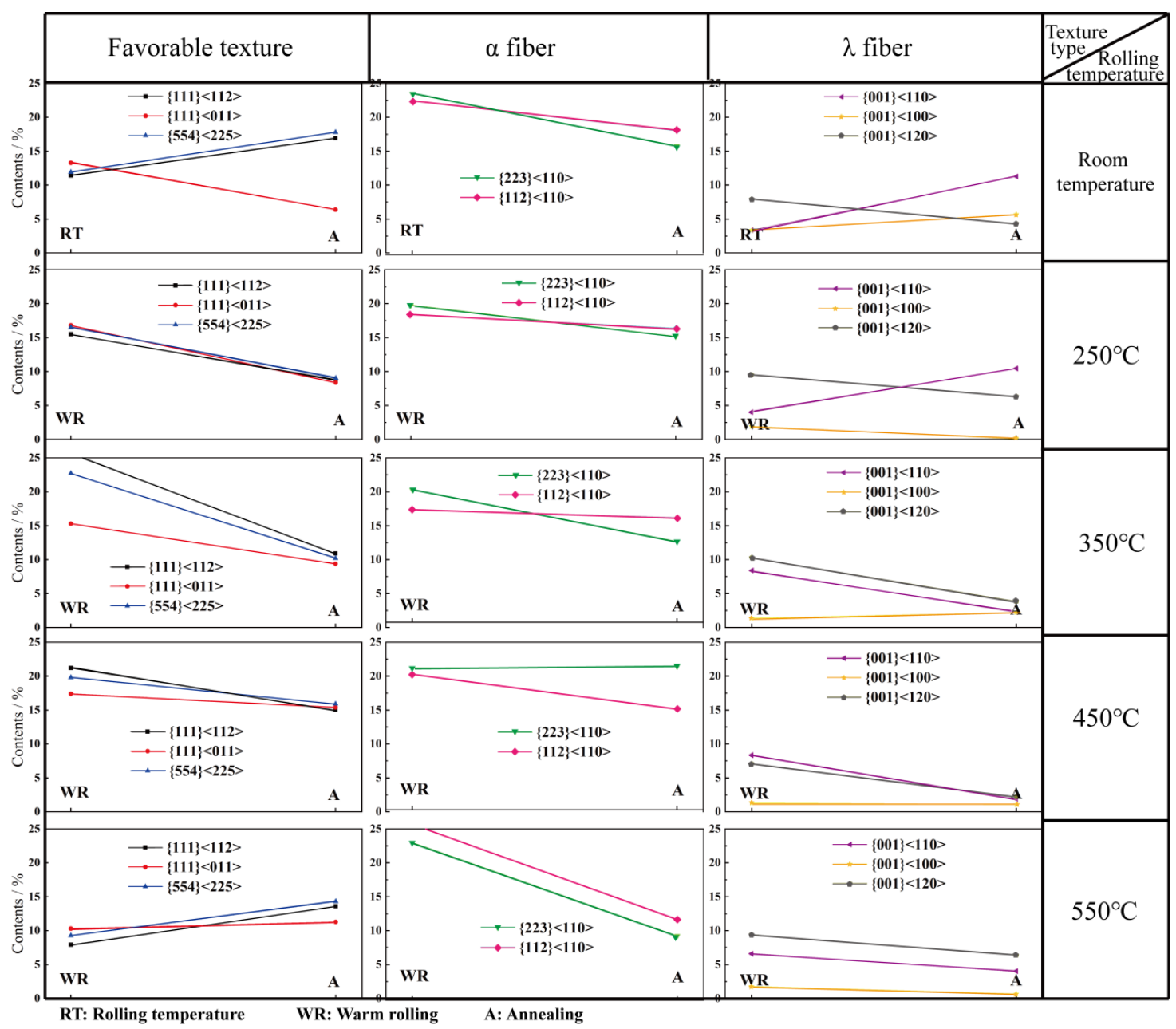

Figure 8. Several typical texture volume fractions of the warm-rolled and annealed sheets.

Table 2. Texture factor of the warm-rolled and annealed sheets $\left(f_{\gamma-\text { fiber }} / f_{(\alpha-f i b e r+\lambda-f i b e r)}\right)$.

\begin{tabular}{cccccc}
\hline Texture Factor/Temperature & $\mathbf{R T}$ & $\mathbf{2 5 0}{ }^{\circ} \mathbf{C}$ & $\mathbf{3 5 0}{ }^{\circ} \mathbf{C}$ & $\mathbf{4 5 0}{ }^{\circ} \mathbf{C}$ & $\mathbf{5 5 0}{ }^{\circ} \mathbf{C}$ \\
\hline Warm-rolled sheet & 0.759 & 0.813 & 0.898 & 1.103 & 0.417 \\
Annealed sheet & 0.578 & 0.575 & 0.643 & 1.006 & 0.685 \\
\hline
\end{tabular}

\section{Discussion}

Generally speaking, warm rolling in low carbon steel is presented when the rolling temperature is lower than the ferrite recrystallization temperature but higher than room temperature rolling [20]. Compared with austenitic rolling, warm rolling avoids the effect of phase transition, thus resulting in more uniform final steel mechanical properties. In the process of warm rolling, the deformation band is an important microstructure. The influence of the temperature on the deformation bands is discussed in this experiment, as gradual form is observed with the rise in rolling temperature due to inhomogeneity deformation and can be related to the local plastic instability during the rolling process [21]. Therefore, the deformation band was not easily generated at room temperature as well as under an excessive temperature (such as $550{ }^{\circ} \mathrm{C}$ ). The dislocation density decreased, the ferrite deformation band widened, and the deformation degree decreased due to dynamic recovery at a rolling temperature of $550{ }^{\circ} \mathrm{C}$. Uniform and narrow deformation bands were formed in specimen at $450{ }^{\circ} \mathrm{C}$ rolling, which provided more nucleation points for martensitic transformation in quenching. In addition, evenly distributed ferrite grain as well as a small and uniformly distributed martensitic phase was also observed. At $250{ }^{\circ} \mathrm{C}$ and $350{ }^{\circ} \mathrm{C}$, the uneven deformation band and the incomplete 
broken pearlite group resulted in the uneven distribution and a larger martensite grain during the annealing process.

The $\alpha$-deformation texture was easily formed during warm rolling. In addition, warm rolling was more likely to produce $\{001\}<110>$ mainly due to the strongest uniform deformation band at $450{ }^{\circ} \mathrm{C}$. Figure 9 a shows the orientation distribution diagram at $350{ }^{\circ} \mathrm{C}$. Figure 9 a presents the mildly deformed $<111>/$ /ND grains (blue color), and Figure $9 \mathrm{~b}$ further indicates the deformed grain belonging to the $\{111\}<112>$ orientation (purple color). In addition, severely deformed and elongated grains that were mainly representative of the $\alpha$-orientation grains (Figure 9c) were observed in the green color area. However, the grain will not stop rotating immediately when the rolling temperature was too high $\left(550{ }^{\circ} \mathrm{C}\right)$. That is, the grain continue to rotate to reach the stable state, such that the experimental results showed that the stable orientation was close to the $<110>/ /$ RD orientation.
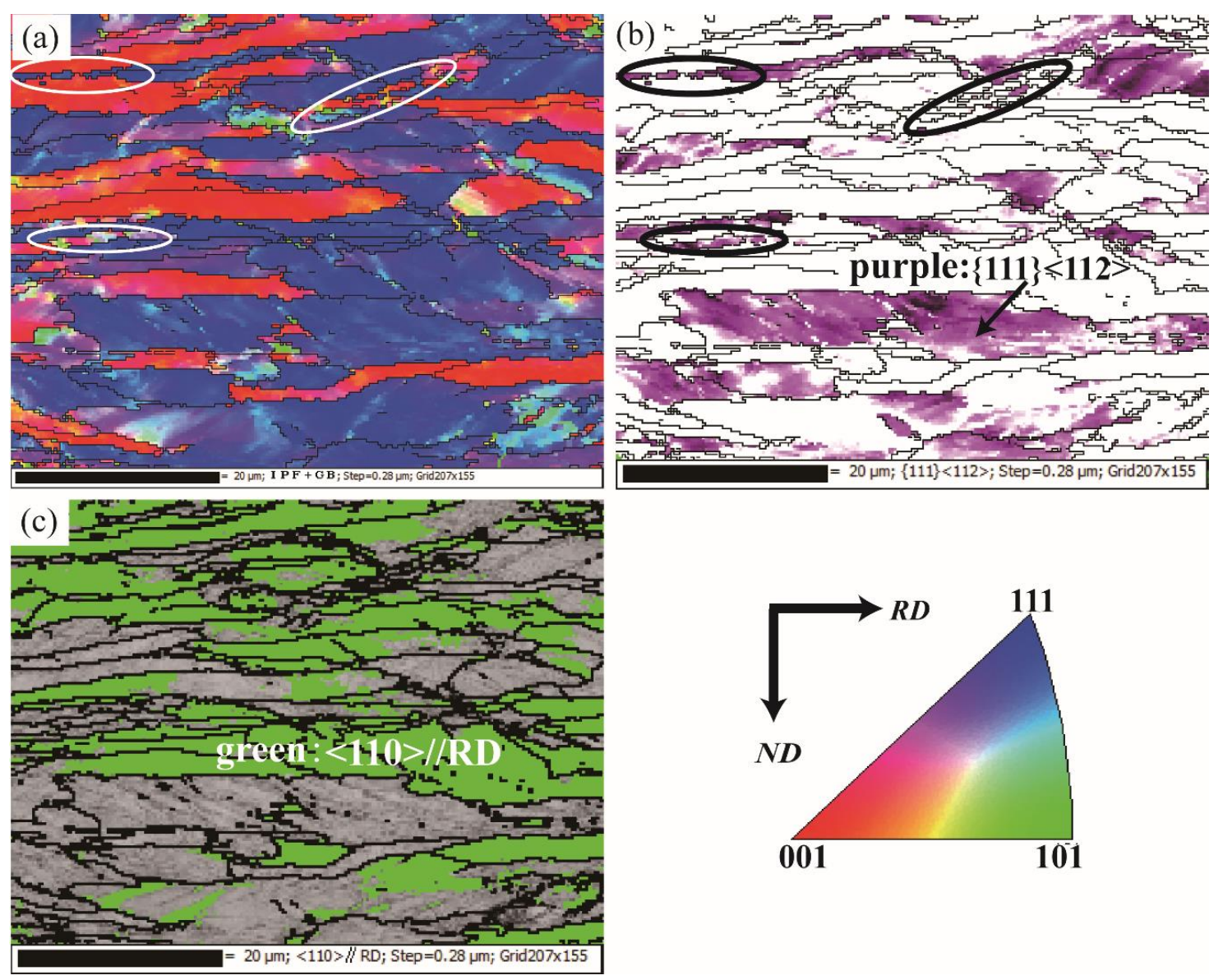

Figure 9. Orientation distribution of the warm-rolled texture. (a) Transitional band and $\{111\}<112>$ grains; (b) $350^{\circ} \mathrm{C} \mathrm{IPF} \mathrm{(inverse} \mathrm{pole} \mathrm{figure);} \mathrm{and} \mathrm{(c)}<110>/ / \mathrm{ND}$ grain distribution.

Deformation bands were formed by the interactions between the dislocations as well as between the precipitates and dislocations, thereby resulting in crystal bending [22]. According to Figure 10a, the dislocation density increased on the $\mathrm{Cr}$-rich carbide region at low temperatures. In addition, the interactions between the dislocations also increased (Figure 10b), thereby resulting in local stress concentration, inhomogeneity deformation, and difficult grain rotation. A transition band was formed between the two deformation bands. The transition band between two $\{111\}<112>$ grains easily formed $\alpha$-texture (Figure 9a,b; white and black line). Precipitate interaction with the dislocation was more likely to occur at higher temperatures when the atomic diffusion rate was equal to the slip rate of the dislocation [23] (Figure 10b). A rolling temperature of $450{ }^{\circ} \mathrm{C}$ induced the precipitates to undergo dislocation pinning as well as resulted in plane slip dislocations, thus promoting deformation band 
production, which resulted in increased $\{001\}<110>$ content [24]. The cellular dislocation substructure was observed and certain grains exhibited dynamic recovery (Figure 10c) as the rolling temperature continued to increase to $550{ }^{\circ} \mathrm{C}$. In addition, unfavorable $\mathrm{C}$ atomic content was observed in the matrix due to the development of deep drawn texture, which served as an effective mean to fixing $C$ by forming carbides. However, no M23C6 carbides were found in the TEM photographs. A similar conclusion was produced based on the JMatPro software calculations (Figure 10d), which showed no M23C6 precipitates at $550{ }^{\circ} \mathrm{C}$, indicating that the $\mathrm{C}$ content of matrix was higher than that ather temperatures, which was not conducive to the development of the deep draw texture. Dynamic recovery was observed at $550{ }^{\circ} \mathrm{C}$, and the dislocation density was sharply released, indicating the likely formation of the $\alpha$-fiber [25].
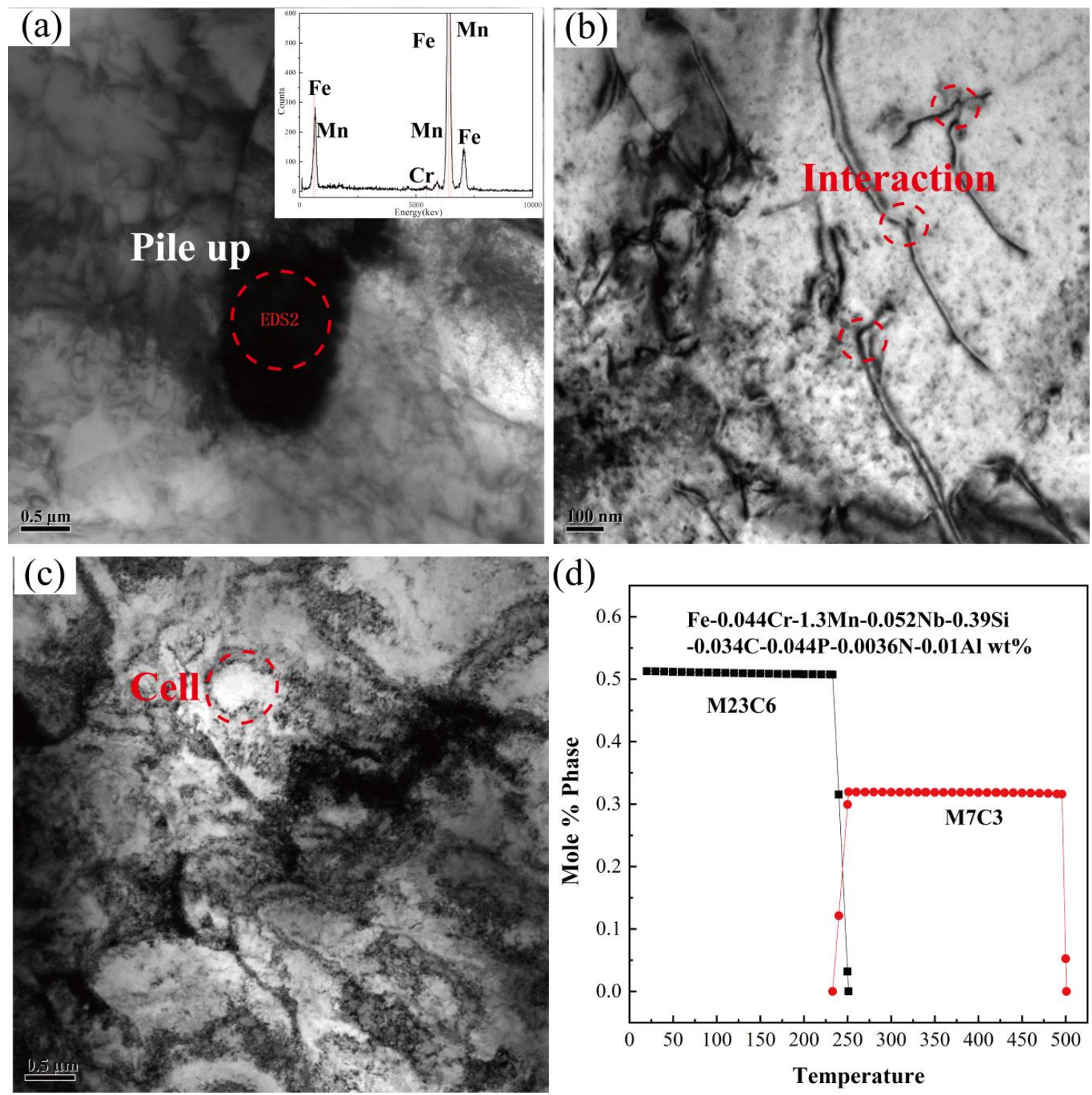

Figure 10. Dislocation density and morphology: (a) $350{ }^{\circ} \mathrm{C}$ and EDS (Energy Dispersive Spectrometer); (b) $450{ }^{\circ} \mathrm{C}$ : interaction (dislocation and precipitated); (c) $550{ }^{\circ} \mathrm{C}$ : cell structure; and (d) precipitate re-dissolution calculations.

The grain with $\gamma$ orientation gradually consumed the grain with $\alpha$-orientation during annealing because the former has relatively higher deformation stored energy. Warm rolling technology promoted the formation of the $\gamma$-deformation texture according to an analysis on the deformation texture, thus promoting the production of the $\gamma$-recrystallization texture, especially for the specimen at $450{ }^{\circ} \mathrm{C}$. 
However, the recrystallization texture was mainly inherited from the hot-rolled sheet. In addition, it was impossible to form recrystallization texture at room temperature rolling. Figures 4 and 7 present a small difference between the main texture types under warm rolling and annealing conditions, especially for the $\gamma$-fiber. These difference were due to the transformation between $\{111\}<112>$ and $\{111\}<110>$ during annealing [26,27]. However, in the annealing, the deformed $\{111\}<112>$ and $\{111\}<110>$ component will be converted to recrystallized $\{111\}<110>$ and $\{111\}<112>$ component correspondingly, indicating an insignificant difference between the two components [28].

The grain orientation and size distribution of the annealed specimens at $450{ }^{\circ} \mathrm{C}$ and $550{ }^{\circ} \mathrm{C}$ were studied to further explore the effect of the warm rolling temperature on the recrystallization texture. The results indicated that the grain orientation of $<111>/ / \mathrm{ND}$ dominated at an annealing of $450{ }^{\circ} \mathrm{C}$. However, many small grains were observed at $550{ }^{\circ} \mathrm{C}$ even after the complete recrystallization. In addition, these grains was mostly likely followed non- $<111>/ / \mathrm{ND}$ grain orientation (Figure 11b; dotted circle). According to Figure $11 \mathrm{c}$, the specimen at $550{ }^{\circ} \mathrm{C}$ exhibited a greater dispersion coefficient (0.74513) compared to the specimen at $450^{\circ} \mathrm{C}(0.68894)$. A normal distribution of the grain size and a relatively uniform ferrite and martensite distribution were observed at $450{ }^{\circ} \mathrm{C}$, indicating mixed crystal microstructure production at a rolling temperature of $550{ }^{\circ} \mathrm{C}$ after annealing.
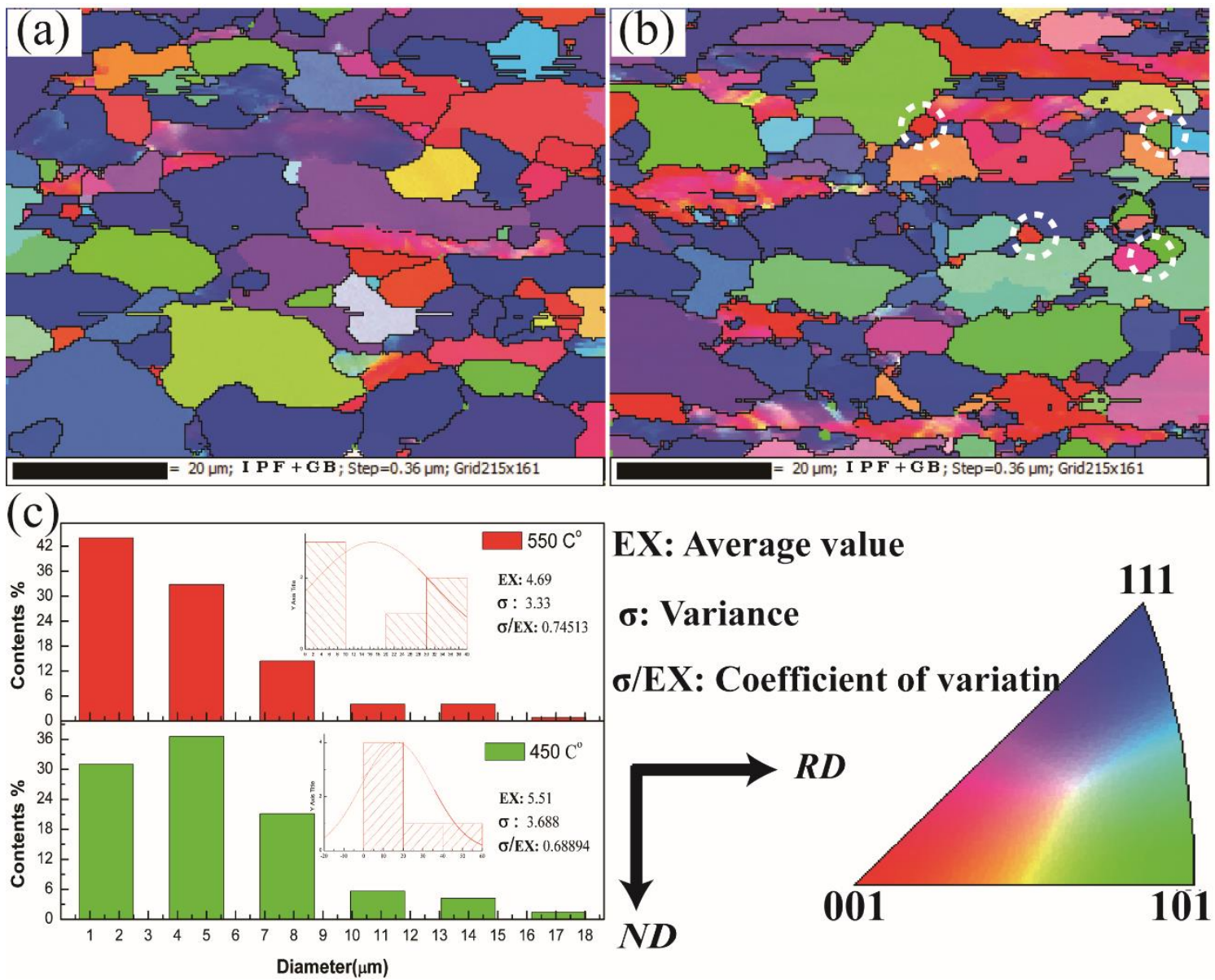

EX: Average value

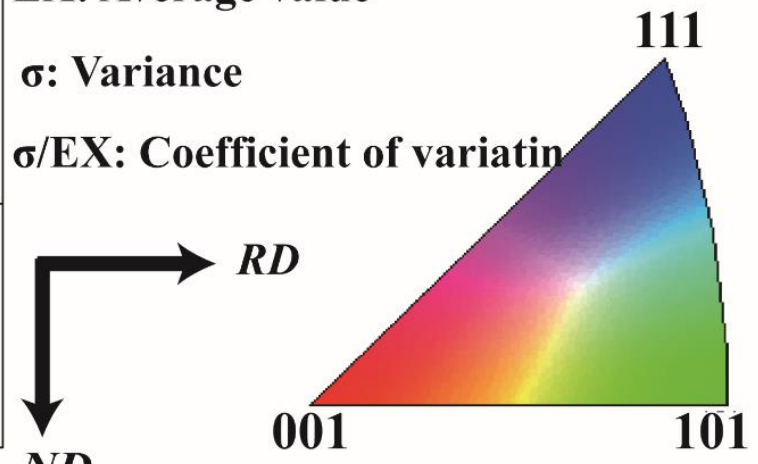

Figure 11. IPF map of the annealing sheet. (a) $450{ }^{\circ} \mathrm{C}$; and (b) $550{ }^{\circ} \mathrm{C}$ : fine grains; and (c) grain size distribution.

\section{Conclusions}

(1) The warm rolling of C-Cr-Nb steel was more conducive to the formation of a deformation band as compared to room-rolling. Deformation bands with higher densities and narrower thicknesses were observed in the sample rolled at $450^{\circ} \mathrm{C}$. The annealed sheet had a ferrite and fine martensite 
microstructure that annealed at the inter-critical region. The ferrite matrix exhibited a much more homogeneous distribution after annealing in the sample rolled at $450{ }^{\circ} \mathrm{C}$ as compared to other rolling temperature.

(2) The $\{001\}<110>$ component was easily obtained after room temperature rolling. The $\gamma$-fiber texture is the dominant texture in rolled samples. With the increase of rolling temperature, $\{223\}<110>$ component gradually changed to $\{112\}<110>$ component, and the $\{001\}<110>$ component gradually disappeared.

(3) An increase in the rolling temperature initially presented a decreased and subsequent increase in the unfavorable texture $\{001\}<110>$ strength in the annealing sheet. The maximum was measured at $550{ }^{\circ} \mathrm{C}$ based on the increase of dissolved carbon in the matrix, which was a result of the dissolution of the chromium-based carbides. By contrast, the intensity of the $\gamma$-fiber and $\{554\}<225>$ component remained relatively high and was deemed the weaker $\{001\}<110>$ component in the annealed sheet after a rolling temperature of $450^{\circ} \mathrm{C}$.

Author Contributions: Conceptualization, Q.Y. and Z.W.; methodology, Q.Y.; software, J.Y.; validation, Z.W., Y.Z. and Q.Y.; formal analysis, Q.Y.; investigation, A.H.; resources, Y.H.; data curation, Z.W.; writing-original draft preparation, Q.Y.; writing_review and editing, Z.W.; visualization, Y.Z.; supervision, Y.Z.; project administration, Y.Z.; funding acquisition, Z.W. All authors have read and agreed to the published version of the manuscript.

Funding: This work was supported by the National Natural Science Foundation of China (Grant Nos. 51704132 and 51601174) and the Key Research and Development Program of Jiangxi Province (Grant Nos. 20192ACB50010 and 20192BBEL50016).

Acknowledgments: The authors would like to thank Goal Science for its technical support in the alloy smelting and processing.

Conflicts of Interest: The authors declare no conflict of interest.

\section{References}

1. Ghosh, P.; Ray, R.K. Deep drawable steels. Automot. Steels 2017, 5, 113-143.

2. Zhao, J.Z.; De, A.K.; Cooman, B.C.D. Formation of the cottrell atmosphere during strain aging of bake-hardenable steels. Metall. Mater. Trans. A 2001, 32, 417-423. [CrossRef]

3. Zhao, Z.Z.; Wang, Z.G.; Zhao, A.M. Microstructure, properties and work hardening behavior of high strength cold rolled dual-phase steel. Adv. Mater. Res. 2011, 618, 182-188. [CrossRef]

4. Han, S.-H.; Choi, S.-H.; Choi, J.-K.; Seong, H.-G.; Kim, I.-B. Effect of hot-rolling processing on texture and r-value of annealed dual-phase steels. Mater. Sci. Eng. A 2010, 527, 1686-1694. [CrossRef]

5. Wang, Z.-G.; Zhao, A.; Zhao, Z.-Z.; Ye, J.-Y.; Chen, J.-J.; He, J.-G. Precipitation behavior and textural evolution of cold-rolled high strength deep drawing Dual-Phase Steels. J. Iron Steel Res. Int. 2013, 20, 61-68. [CrossRef]

6. Barnett, M.R. Influence of Warm Rolling Temperature on Ferrite Recrystallization in Low C and IF Steels; McGill University; National Library of Canada: Ottawa, ON, Canada, 1996; pp. 57-76.

7. Jonas, J.J. Effects of shear band formation on texture development in warm-rolled IF steels. J. Mater. Process. Tech. 2001, 117, 293-299. [CrossRef]

8. Romani, N.; Humphreys, A.O.; Jonas, J.J. Effect of chromium addition on the warm rolling behaviour of low carbon steels. Can. Metall. Q. 2006, 45, 451-457. [CrossRef]

9. Nagesha, A.; Kannan, R.; Srinivasan, V.S.; Sandhya, R.; Choudhary, B.K.; Laha, K. Dynamic strain aging and oxidation effects on the thermomechanical fatigue deformation of reduced activation ferritic-martensitic steel. Metall. Mater. Trans. A 2016, 47, 1110-1127. [CrossRef]

10. Zhou, H.; Bai, F.; Yang, L.; Wei, H.; Chen, Y.; Peng, G.; He, Y. Mechanism of dynamic strain aging in a niobium-stabilized austenitic stainless steel. Metall. Mater. Trans. A 2018, 49, 1202-1210. [CrossRef]

11. Mohammad, R.T.; Fakhraddin, A.; Abbas, N. Effect of rolling temperature on the deformation and recrystallization textures of warm-rolled steels. Metall. Mater. Trans. A 2003, 34, 1163-1174.

12. Cuddy, L.J.; Leslie, W.C. Some aspects of serrated yielding in substitutional solid solutions of iron. Acta Metall. Sin. Engl. 1972, 20, 1157-1167. [CrossRef] 
13. Storozheva, L.M.; Burko, D.A.; Grinberg, E.; Rodionova, Y.E.; Bode, R.; Esher, K. Effect of niobium on recrystallization of ultralowcarbon cold-rolled automobile sheet steel. Met. Sci. Heat Treat. 2000, 42, 267-271. [CrossRef]

14. Song, X.L.; Peng, K.; Yuan, Z.X.; Zhu, W.W.; Jia, J.; Deng, Z.J. Effect of Micro-Alloying Elements of Ti, Nb and B on Recrystallization Behavior of Cold-Rolled Interstitial-Free Steel Sheets. Mater. Sci. Forum 2013, 753, 207-212. [CrossRef]

15. Anijdan, S.H.M.; Hoseini, M.; Yue, S. Texture development in cool deformed microalloyed steels. Mater. Sci. Eng. A 2011, 528, 6788-6793. [CrossRef]

16. Gao, W.; Leng, Y.; Fu, D.; Teng, J. Effects of niobium and heat treatment on microstructure and mechanical properties of low carbon cast steels. Mater. Des. 2016, 105, 114-123. [CrossRef]

17. Chen, R.C.; Wang, Z.G.; Zhu, F.S.; Zhao, H.J.; Qin, J.; Zhong, L.Q. Effects of rare-earth micro-alloying on microstructures, carbides, and internal friction of 51CrV4 steels. J. Alloy. Compd. 2020, 824, 153849. [CrossRef]

18. Fan, X.-G.; Zeng, X.; Yang, H.; Gao, P.; Meng, M.; Zuo, R.; Lei, P.-H. Deformation banding in $\beta$ working of two-phase TA15 titanium alloy. Trans. Nonferrous Met. Soc. China 2017, 27, 2390-2399. [CrossRef]

19. Zhang, Y.H.; Yuan, Q.Q.; Ye, J.Y.; Weng, X.; Wang, Z. Effect of cold rolling reduction on microstructure, mechanical properties, and texture of deep drawing dual-phase (DP) steel. Mater. Res. Express. 2019, 6, 125802. [CrossRef]

20. Ahmer, W.M.; Hunt, G.W.; Peletier, M.A. Kink band instability in layered structures. J. Mech. Phys. Solids 2004, 52, 1071-1091.

21. Guo, N.; Song, B.; Luan, B.; Chen, Z.; Liu, Q. Deformation bands in fully pearlitic steel during wire drawing. Sci. China Ser. E: Technol. Sci. 2014, 57, 796-803. [CrossRef]

22. Zhao, X.; Lu, C.; Tieu, A.K.; Pei, L.; Zhang, L.; Su, L.; Zhan, L. Deformation mechanisms in nanotwinned copper by molecular dynamics simulation. Mater. Sci. Eng. A 2017, 687, 343-351. [CrossRef]

23. Aboulfadl, H.; Deges, J.; Choi, P.; Raabe, D. Dynamic strain aging studied at the atomic scale. Acta Mater. 2015, 86, 34-42. [CrossRef]

24. Cizek, P.; Wynne, B.; Hong, L.; Parker, B. Deformation banding in (001)[110] textured aluminium sheet deformed in tension. Mater. Sci. Eng. A 1996, 219, 44-55. [CrossRef]

25. Cheng, L.; Cai, Q.-W.; Lv, J.; Yu, W.; Miura, H. Superdense microbands strengthening of textured low alloy ferritic steel. J. Alloy. Compd. 2018, 746, 482-489. [CrossRef]

26. Park, J.T.; Szpunar, J.A. Evolution of recrystallization texture in nonoriented electrical steels. Acta Mater. 2003, 51, 3037-3051. [CrossRef]

27. Li, X.; Yang, P.; Meng, L. Formation of the $\{111<112>$ and $\{111<110>$ recrystallization texture in deep drawing low carbon steel. Adv. Mater. Res. 2012, 535-537, 687-691. [CrossRef]

28. Boumaiza, A.; Rouag, N.; Baudin, T.; Larouk, Z.; Penelle, R. Characterisation of transgranular crack propagation by EBSD in a soft steel. JPCS 2010, 240, 012036. [CrossRef] 